\title{
How to use Lego Serious Play as a Gamification Teaching and Learning Framework? A Responsible Management Approach
}

\author{
Vasilis Gkogkidis ${ }^{a} \&$ Nicholas Dacre ${ }^{a}$
}

${ }^{a}$ University of Southampton Business School, University of Southampton, Southampton, SO17 1BJ, UK

* Corresponding Author: v.gkogkidis@southampton.ac.uk

\begin{abstract}
This paper conceptualises a Lego Serious Play Wheel framework as a gamification teaching and learning method. It aims to offer a detailed approach from Design and Preparation to Delivery, to engage a broad section of continuing learners and students, which can be easily applied throughout different educational and training contexts. The LSP Wheel refers to the concept of a circular learning journey and draws on a combined autoethnography responsible management research approach. A prominent part of the responsible management literature has hitherto focused on examining whether responsible management modules are inherently considered non-crucial elements of curriculum design. However, there is a paucity of research into applying novel teaching approaches to engage students and promote responsible management education endeavours. This paper therefore contributes to broader pedagogical application and critical responsible management education discourse, by providing educators with an academic gamification framework to support student engagement and co-creation of knowledge, by fostering exploratory learning environments and enriching the practices of active learning communities.
\end{abstract}

Keywords: Lego Serious Play, LSP, Gamification, Teaching, Learning, Responsible Management, Education, Project Management, LSP Wheel.

\section{Acknowledgements}

The authors would like to acknowledge the countless learners who participated in helping conceptualise this gamification framework using Lego Serious Play. As a certified Lego Serious Play Facilitator, the first author also acknowledges the input from international partners in facilitating corporate Lego Serious Play sessions that helped inspire this study's development.

\section{Citation}

Gkogkidis, V., \& Dacre, N. (2021). How to use Lego Serious Play as a Gamification Teaching and Learning Framework? A Responsible Management Approach. SBS Working Paper Series. https://dx.doi.org/10.2139/ssrn.3829949

\section{Introduction}

Business schools play a vital role in educating and shaping future global leaders' mindsets, as they aim to offer a rich environment of deep analysis, entrenched engagement, and thought-provoking discourse (Harrison et al., 2007). Their role also extends beyond the academic world's confines as they have increasingly become embedded in their respective national economies (Thorpe \& Rawlinson, 2013), where they help foster innovations by collaborating with industry, academic experts, and thought-leaders (Minshall \& Wicksteed, 2005). 
Furthermore, as the relationship between society, the environment, and business becomes ever-more intertwined, business schools and educators have an increasingly intricate role in signifying the complexity of these elements to help develop socially responsible professionals that can draw on an ethical management ethos, and apply it to future practice (Dyllick, 2015; Godemann at al., 2014). The concept of responsible management education promotes such aims, with crucial principles underpinned by organisations such as the United Nations (Stefanova \& Stefanova, 2013). However, responsible management education has hitherto focused mainly on what constitutes corporate social responsibility (CSR) elements and how these should be embedded into the curriculum (Aragon-Correa et al., 2017; Dyllick, 2015).

In part, this has been driven by a delineated interpretation of responsible management education topics. For example, there has been a focus on content that is salient to execution, and therefore driven by the analysis of the plethora of social, economic, and environmentally aware subjects which may bear relevance to business school education contexts (Muff, 2013). These include elements such as sustainable supply chains, CSR and the circular economy (Snelson-Powell et al., 2016). Nonetheless, business schools have been criticised for their lack of progress in recognising the importance of these responsibility-aware topics (Dyllick, 2015).

In turn, this has focused institutions and educators on the premise of content-driven responsible management education, with limited recognition of the processes of engagement and delivery. Notwithstanding the importance of this focus, business schools and educators are facing complex teaching and learning challenges in order to deliver these subjects in a way that matters most for their audience, in this case students, who represent future practitioners (Dacre et al., 2019; Ojiako et al., 2011). As such, by bringing together constructivist learning theories like exploratory learning environments (Duckworth, 2006; Rick \& Lamberty, 2005), organisational sustainability teaching frameworks (Stubbs \& Cocklin, 2008) and empirical research on the use of the Lego Serious Play (LSP) methods in educational settings (James, 2013; Kurkovsky, 2015; Mccusker, 2014)

This paper aims to conceptualise LSP as an innovative teaching method that utilises Lego bricks to improve student engagement and participation, create exploratory teaching environments that can support learning, and help shape responsible organisational leaders. Therefore, the focus of this paper offers a departure from prior research focused on what constitutes responsible management education content to provide a framework on how to engage in the teaching and learning process of this content.

\section{Responsible Management Education}

Responsible management education can be defined as the educational practices aiming to facilitate students' learning on issues like CSR, the social impact of organisations on the larger societies they are embedded in, and the impact organisations have on the preservation of the environment (Forray \& Leigh, 2012). The more significant issues of managing organisations ethically and how these impact everyday decisions and practice are also included in the responsible management curriculum (Godemann et al., 2014).

Discourse calling for business schools to promote a more responsible management curriculum has increasingly gathered support in management education literature, but adapting the curriculums of business schools to this has proved to be a more challenging task than initially expected (Parkes et al., 2017; Rasche et al., 2013, Rasche \& Gilbert, 2015).

One of the main issues around implementing a responsible management curriculum is that business schools have not made such courses mandatory for all students, with $75 \%$ of these modules offered as electives, thus remaining detached from core disciplines (Rasche et al., 2013).

Similar conclusions were drawn by the Principles for Responsible Management Education (PRME, 2014), indicating that, even though there have been the curriculum additions of CSR and sustainability modules, they are not yet the central focus of business management education, thus failing to effectively address the challenge in encouraging more responsible future organisational leaders (Rasche \& Gilbert, 2015). This paper suggests that for such efforts to be more impactful, educators should think beyond the learning content and consider innovative teaching approaches that would strengthen learning sessions. 
The quality of teaching and learning practices in business schools has been previously challenged by scholars, suggesting that business schools are somewhat ineffective in equipping students with the necessary skills and knowledge to tackle complex organisational challenges (Pfeffer \& Fong, 2002; Bennis \& O'toole, 2005; Taylor et al., 2002).

Even though organisations generally prefer exploratory, hands-on pedagogies when it comes to management training (Gold \& Holman, 2001), business schools have commonly not taken the same approach, and have in some instances ignored participatory teaching methods and tools during learning sessions (Mello, 2006; Eckhaus et al., 2017).

\section{Gamification}

Recognising the need for improved student engagement and participation, teaching staff in higher education has introduced a plethora of gamification tools in the classroom, such as board games, digital games, simulations and role-playing activities (Feinstein et al., 2002; Wyss-Flamm \& Zandee, 2001). Gamification can be defined as "the use of game design elements in non-game contexts" (Deterding et al. 2011, p. 9).

Extant gamification research suggests that the implementation of game-based elements can enhance engagement and foster more significant interaction (Dacre, Constantinides, \& Nandhakumar, 2015; Nacke \& Deterding, 2017; Robson et al., 2015, 2016). Fotaris et al. (2016), suggest that gamification can be an effective tool when successfully implemented to increase student engagement with teaching and learning practice.

According to Dacre et al. (2018, P.1), gamification also "offers the prospect of providing a pivotal shift from traditional asynchronous forms of engagement, to developing methods to foster greater levels of synchronous interactivity and partnership between and amongst teaching and learning stakeholders". Such endeavours seek to increase student engagement and facilitate active learning by involving students in the educational process more than instructional teaching approaches (Dacre et al., 2018; Gkogkidis \& Dacre, 2020). When applied as a gamification concept, LSP is also increasingly being recognised as an innovative and adaptable method for teaching and learning practices in higher education (Peabody \& Noyes, 2017).
A growing body of literature examines the merits and application of LSP as a teaching method, with studies reporting improvement in student engagement, participation, knowledge co-creation and knowledge retention (Grienitz \& Schmidt, 2012; James, 2013; Mccusker, 2014).

With LSP having successfully been utilised in different knowledge domains such as computer science (Kurkovsky, 2015) and management education (Grienitz \& Schmidt, 2012) this paper suggests that LSP can enable educators to embed the values of constructivist learning theories into their teaching practices and operationalise exploratory learning environments to enhance student engagement and participation.

\section{Exploratory Learning Environment}

Rick \& Lamberty (2005) define exploratory learning environments as educational arrangements and activities that facilitate the learners' ability to construct knowledge connected to the subject matter through student-led reflective exploration. Exploratory learning activities can promote an increased democratic style of education and, according to Duckworth (2006, p. 67) can guide students towards:

- Building their understanding, influenced by their academic interests through exploring questions provided by educators.

- Making a connection between the knowledge and experiences they already have and the learning material, thus building new knowledge through interpreting the material according to their worldview.

- Openly sharing ideas with their peers by asking for feedback. Students first shape their ideas, then share them with their peers and work out how different ideas relate to each other and the subject matter.

Exploratory learning environments enable student participation in learning processes by offering their ideas and interpretation of the knowledge under discussion. Educators adopt a facilitative rather than prescriptive role to create educational experiences based on values of constructivist learning theories (Bruner, 1961). 
Different perspectives have been shared by later scholars such as King (1993), arguing for a shift in the educator's role from 'sage-on-the-stage' to 'guideon-the-side', facilitating learning rather than imposing it.

LSP as a teaching method embodies constructivist learning theories emphasising exploration where "to understand is to discover, or reconstruct by discovery" (Piaget, 1972, p. 20) while at the same time there must be a recognition of knowledge being created in specific cultural contexts among educators and learners (Vygotsky, 1980).

Exploratory learning environments facilitate knowledge communities where their members participate in their practices purposefully, with knowledge residing in the specific context used (Hickey \& Zuiker, 2005).

Prior student knowledge and experiences, as influenced by their social and cultural environment, are a crucial element of the learning processes that help construct knowledge and, thus, ideally be discussed and negotiated among students and educators (Salomon, 1997). In engaging with responsible management curricula, students and educators aim to produce and negotiate knowledge that will inform future ethical management practices.

Both undergraduate and postgraduate student cohorts in business schools come from a variety of different national and cultural backgrounds, with many of them, especially those undertaking postgraduate courses, having prior experience of management in organisations (Arbaugh et al., 2010; Jabbar \& Hardaker, 2013; Tompson \& Tompson, 1996).

Bringing these student experiences and knowledge to the forefront by discussing and negotiating rather than ignoring them is a challenge that LSP can assist educators with, as a methodology designed around active and egalitarian participation values.

Finally, constructivist theories suggest that students' new knowledge is added to existing knowledge schemes, mental models that keep expanding when new understandings are achieved (Hoidn, 2017). This idea is especially pertinent to responsible management education.
Students with existing knowledge of management theories and practices are offered the opportunity to enhance their knowledge with responsible management frameworks, assisting them in a more sustainable type of management.

\section{The Lego Serious Play Wheel}

We draw on the responsible management education and exploratory learning environment approaches, discussed as part of the theoretical context to outline a teaching and learning approach to applying practice-based LSP. The resultant LSP teaching and learning framework titled "LSP Wheel" referring to the concept of a learning journey, is thus presented here (Figure 1).

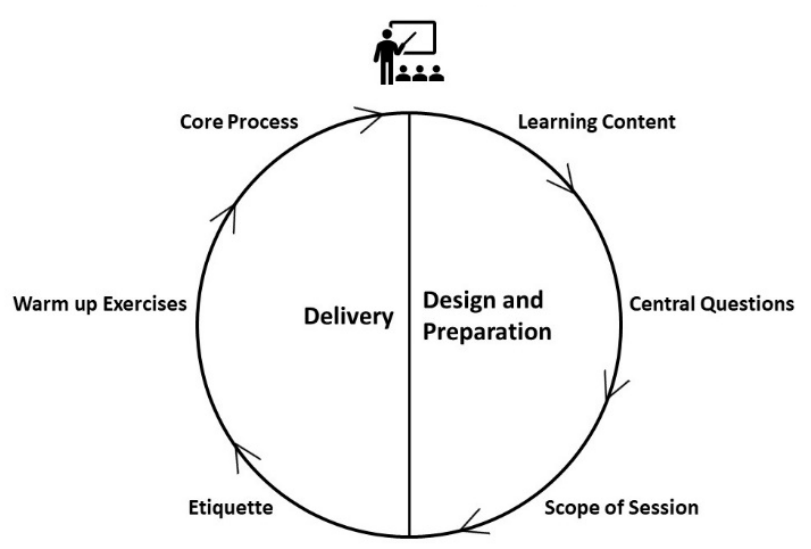

Figure 1: Lego Serious Play Wheel

The framework incorporates two main phases for designing and facilitating educational sessions using LSP: Design and Preparation; and Delivery. This is further supported across the following approach: (1) Learning Content; (2) Central Questions; (3) Scope of Session; (4) Etiquette; (5) Warm up Exercises; and (6) Core Process.

\section{Design \& Preparation Phase}

The design and preparation stage of the framework adopts the following process (Figure 2). Educators can use this to assist design responsible management educational LSP sessions.

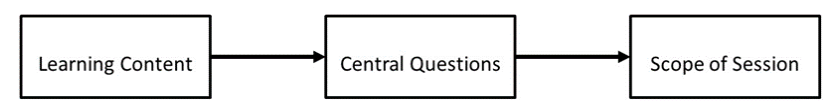

Figure 2: Design \& Preparation Phase 
The learning content should be the starting point and cornerstone of every educational LSP session. During this stage, educators can identify what learning content they want to deliver, for example a case study or more theoretical content around responsible management.

LSP is a time-intensive activity where lecturing should be kept to a minimum, making LSP more suitable for seminar sessions where student numbers are smaller than lectures. The second step when designing an LSP session involves designing questions that will allow students to reflect on the learning content and contribute their opinion and understanding.

Educators are advised to design questions that are accessible and inclusive for all students to answer, while being beneficial for the educators in order to connect theory with practice. Finally, educators need to decide what the scope of the session depends on, the provided amount of time, and the number of students present.

Questions identified as appropriate for the session need to be prioritised as time constraints might make it challenging for the entire range of questions to be discussed within a single session. Using an organisational sustainability teaching paper (Stubbs \& Cocklin, 2008) as an example, the following section outlines how educators can apply the suggested design and preparation framework in order to design practical LSP learning sessions.

\section{Step 1: Learning Content}

Providing new teaching methodologies to support a better understanding of sustainability concepts in management education (Cervantes, 2007), Stubbs \& Cocklin (2008) suggest a pedagogical approach where educators present students with a typology of business sustainability practices, followed by two case studies of organisations that engage in business sustainability practices.

The suggested typology describes organisations following an eco-centric approach striving to create closed-loop systems where unused materials belonging to one organisation in the system are used as an input for another organisation (Stubbs \& Cocklin, 2008), and destruction of environmental resources is minimised by sharing infrastructure between organisations (Ayres \& Ayres, 2002).
Organisations designed around the idea of ecological modernisation aim at profitability while contributing to the wellbeing of the organisation's stakeholders, and keeping environmental impacts like pollution to a minimum (Gladwin et al., 1995). Finally, neoclassical organisations measure all of their activities based on their economic outcomes, where sustainability is not part of their core strategy unless they strive to increase profits by strengthening their competitive advantage, comply with legislation, address concerns and pressure from the public, or are pressured by stakeholders (Banerjee, 2001; Bansal \& Roth, 2000; Shrivastava, 1995).

To support the understanding of the above theoretical concepts of organisational sustainability and facilitate student reflexivity during learning sessions, Stubbs \& Cocklin (2008) suggest using realworld case studies describing organisations implementing such practices.

Combining case studies with theory to teach business ethics is an established practice in business schools (Cagle \& Baucus, 2006; Feldman \& Thompson, 1990; Shannon \& Berl, 1997), and one that can be combined effectively with the LSP methodology. Providing a case study to students at the beginning of a session can underpin a reflective process where students and educators negotiate their understanding of the learning content and explore emergent themes.

In their paper, Stubbs \& Cocklin (2008) outline two case studies, one from the banking industry and one from the automotive industry, but do not offer a reference for these case studies. We suggest publications by Hamschmidt (2007) and Vives Gabriel (2017), which offer case studies that educators can use to teach sustainability and ethical management approaches.

Having determined the learning content of a session, educators can now design the main questions students should engage with during the LSP session.

\section{Step 2: Central Questions}

Looking to provide central focus learning points for their students, Stubbs and Cocklin (2008) offer the following list of questions for students to assist in their analysis of an organisational sustainability case study, and connect it with theoretical knowledge gained during the module: 
- What are the main sources of income for the organisation?

- What are the main sustainability problems and risks that the organisation is facing? Risks can be categorised as environmental, social and economic.

- How can these different risk factors impact the organisation? (Students are encouraged to produce a risk matrix at the end of the exercise, rating the likelihood and impact of each risk.)

- What are the potential solutions to these problems and risks, and what should the business do to solve these issues?

Taking the last question that was mentioned above as an example, educators can motivate students to consider issues such as the strategies the organisation might follow to tackle these challenges, such as; lead the industry by shaping it or follow trends and mimic what other organisations in the same industry are doing; focus on a small number of products and services or diversify to new products and services.

Students are also encouraged to reflect on the impact these strategies might have on the organisation, such as whether there are changes needed in terms of the structure, the systems in place, and the organisation's culture and capabilities (Stubbs \& Cocklin, 2008). Different learning content might call for different questions, but the main takeaway from this second step of the framework is that having a list of central questions can help focus the LSP session and provide a fertile ground for discussion.

\section{Step 3: Scope of Session}

Having identified a list of leading questions, the final stage of designing an LSP session is to prioritise these and select how many should be discussed during a session based on time constraints and the number of participants. Additionally, identifying each session's learning outcomes can help prioritise the main questions before deciding how many should be included within the session. Within this approach, there are three key issues that educators should consider when outlining the scope of the session; (i) how long the learning session should last; (ii) the size of the student cohort; and (iii) the amount of content which will be delivered during the session. In achieving these points, we also recommend that educators design a detailed learning plan, and time each activity before delivering an LSP learning session.

In appendix 1, we illustrate a learning plan which aims to provide a framework for educators that want to deliver one-hour responsible management seminars fusing case studies on organisational sustainability with the LSP methodology. The purpose of this example is to offer a better understanding of the structure of an LSP learning session in practice.

The first time you introduce a group of students to LSP, warm-up exercises are of paramount importance for the students to understand how the LSP methodology works. Facilitating warm-up exercises means that you have less time for case study related questions, so the very first session might include one case study related question, unlike the following Lesson Plan that includes two.

\section{Delivery Phase}

The LSP methodology offers a framework to support the delivery of learning sessions, during which participants are led through a series of exercises where they build Lego models in response to the educator's questions (Roos et al., 2004). The Lego models aim to help participants share their insights about the question at hand by using metaphors rather than to accurately represent entities found in the physical world (Grienitz \& Schmidt, 2012). For example, a single yellow Lego brick can represent the sun or a banana or a sandy beach. Meaning is embodied in the bricks by the model's creator to support them in answering the question that is under discussion.

LSP realises constructivist learning theories and values by offering educators a framework to design learning environments where participants get to participate in social processes that help them learn from their teachers and peers. Central to the LSP methodology is the idea of constructing knowledge from previous knowledge and experiences by getting workshop participants together and encouraging them to use Lego materials to make and express meaning that they share with their peers (Roos, Victor \& Statler, 2004). LSP offers an etiquette for participants and facilitators to follow and a core 
process which includes four stages of facilitation: the educator poses a question, students construct a Lego model answering the question, students share the meaning of their Lego models, and finally the educator and students share reflections on the meanings shared (Kristiansen \& Rasmussen, 2014).

\section{Step 4: Etiquette}

When facilitating LSP sessions for a student cohort for the first time, educators are advised to present one slide listing the guidelines that inform interaction between students during the workshop and try to reinforce these behaviours during the warm-up exercises.

\section{Everyone Builds}

All students are expected to engage in building models using their Lego bricks; if a student is hesitant, try to motivate them by advising them to start building, even if they do not know what their model will represent. We have also found it beneficial to participate and build our models during warm-up exercises. Students feel more at ease when educators participate and are viewed as an excellent example for students.

\section{Everyone Shares}

All students are expected to share their models' meaning, sharing their perspectives and insights about the case discussed and participating in the social co-creation of knowledge. Students must explain their model must be respected and there should be no disruption even from the educator.

\section{The Meaning of the Model Belongs to its Owner}

The insights shared by each student should be respected and not be interpreted in any other way, not by other students or the educator.

\section{Ask Questions About the Model not the Student}

After a student has shared their insights, either the rest of the student cohort or the educator can ask to follow up questions about the presented model. Questions should be focused on the model rather than the student.

\section{Step 5: Warm-Up Exercises}

When facilitating LSP sessions for a student cohort for the first time, educators are advised to present one slide listing the guidelines that inform interaction between students during the workshop and try to reinforce these behaviours during the warm-up exercises.

\section{Everyone Builds}

All students are expected to engage in building models using their Lego bricks; if a student is hesitant, try to motivate them by advising them to start building, even if they do not know what their model will represent. We have also found it beneficial to participate and build our models during warm-up exercises. Students feel more at ease when educators participate and are viewed as an excellent example for students.

\section{Everyone Shares}

All students are expected to share their models' meaning, sharing their perspectives and insights about the case discussed and participating in the social co-creation of knowledge. The time students have to explain their model must be respected and there should be no disruption even from the educator.

\section{The Meaning of the Model Belongs to its Owner}

The insights shared by each student should be respected and not be interpreted in any other way, not by other students or the educator.

\section{Ask Questions About the Model not the Student}

After a student has shared their insights, either the rest of the student cohort or the educator can ask follow up questions about the presented model. Questions should be focused on the model rather than the student.

\section{Step 6: Core Process}

The core process of LSP is comprised of four elements; (i) Pose Question; (ii) Construct Models; (iii) Share Meaning; and (iv) Reflections. These four elements are represented in the following model as a loop starting from posing a question and ending in reflection before starting again with the following question (Figure 3).

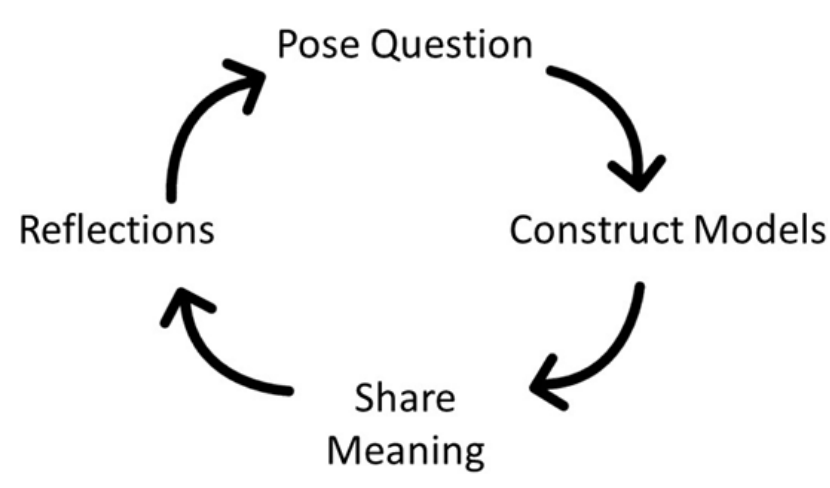

Figure 3: Core Process 
The first element of the LSP core process is 'Pose Question', where the educator poses a question to the students. Adhering to the LSP etiquette guidelines where everyone builds and everyone shares, questions should be accessible to all students, even those who have not done the required reading. Educators should strive to design questions that allow students to reflect on their own experiences while allowing them to connect student insights to the theoretical knowledge discussed in the classroom.

This introduction to the question presents educators with the opportunity to assist students in conceptualising the central ideas or frameworks that they are supposed to engage with when answering the question with their Lego models. A very brief explanation of how the question is relevant to the case or theory discussed during the session can be helpful, especially if students do not know how to answer the question immediately.

After the question is given, an exact time must be set for the students to construct their models. The time given for the construction of models depends on the level of challenge and the time available. Three to five minutes is a good rule of thumb in most cases, the students have already engaged with the learning material or have some prior knowledge of the case discussed.

The second element of the core process is 'construct models', during which students build using their bricks. Again, LSP might be unusual, but we would advise educators to build their models and participate in the discussion. Students should be reminded not to communicate with their classmates to concentrate on incorporating their insights into their brick models without getting influenced by their peers.

Students who may be hesitant to construct Lego models could be motivated by educators to start putting together some Lego bricks even if they are unsure what they are making. Starting building can be helpful to convince hesitant students to participate. Students might also be hesitant to build because they did not understand the question, in which case educators need to offer further explanations to these students individually. Educators must make sure that the time allocated to all students for constructing their models is respected and warn students when time is about to run out. An advice often given during LSP workshops is that anything that is not on the table will be shortly forgotten, meaning that all ideas embodied in the Lego models and shared by students will be more memorable than insights that are not part of the Lego model.

The third element is 'share meaning'. After students have completed their Lego models, educators ask them to take turns sharing the meaning of their models with the rest of the classroom, explaining what their insights and ideas about the learning content under discussion are (Figure 4).

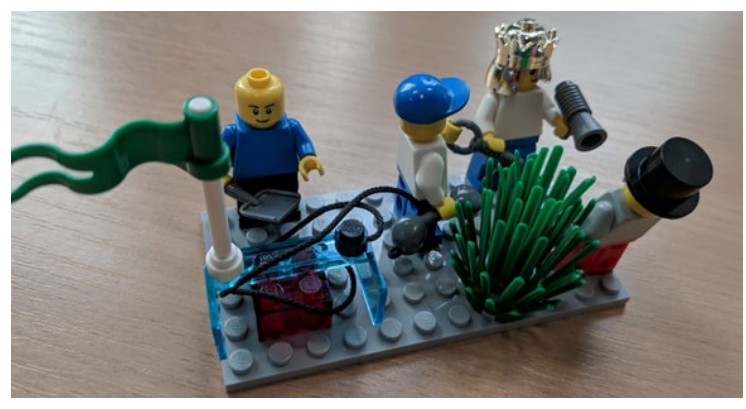

Figure 4: Concept Sharing

Thinking of time constraints, educators can give students and themselves one minute to share the meanings of their Lego models. After a student has finished sharing the meaning of their model, explanatory questions can be asked by the educator or the rest of the class to either clarify unclear parts of the description or help the student reflect on their model and how it connects to the more extensive theoretical discussion.

The focus of the follow-up questions should be on the model and not the student. It is the responsibility of the educator also to make sure that everyone respects the insights that are shared.

The fourth element is 'reflections'. During this last step of the LSP core process students are asked to briefly summarise the discussion and insights shared by the classroom and organise them into themes. The educator's role is to connect the themes and insights shared with the knowledge that is being introduced during the module and the theoretical aspects that students might struggle to understand. In the interest of time, the educator can identify themes and summarise the discussion themselves (instead of the students) before connecting the discussion with the larger body of knowledge that is being negotiated. 
The 'share meaning' and 'reflections' steps of the process provide salient examples of the social creation of knowledge theory (Vygotsky, 1980; Hickey \& Zuiker, 2005) in practice, where the themes shared by the students and the educator reveal how new knowledge is created and negotiated between a learning community, while at the same time being influenced by the social and cultural context of the learning community. LSP is a pedagogical process where meaning and ideas can be unpacked and negotiated among the members of the learning community, offering the opportunity for pluralistic learning experiences, including a diversity of different voices.

\section{Discussion \& Future Research}

This study has sought to conceptualise a gamification teaching and learning framework by applying Lego Serious Play. Gamified teaching approaches, which include LSP, present a salient opportunity for educators to enhance student engagement and strive towards a more open and inclusive teaching paradigm (Cook-Sather et al., 2014; Bovill et al., 2011; Gkogkidis \& Dacre, 2020. The emergent 'LSP Wheel' framework outlines a process that can help educators design and deliver LSP learning sessions. Our research suggests that this is an area which has hitherto received limited attention (Aragon-Correa $e t$ al., 2017; Dyllick, 2015; Muff, 2013; Snelson-Powell et al., 2016), whereas we have argued that content, as well as delivery, plays a vital role in preparing and shaping the characteristics and thinking processes of future leaders (Dacre et al., 2019).

Through the use of the increasingly popular LSP approach, which is utilised globally as a multitier approach to solving business, environmental, economic, and social issues (Grienitz \& Schmidt, 2012; Kurkovsky, 2015; Peabody \& Noyes, 2017), we offer a pragmatic approach with practical steps to implement and deploy this framework. However, this research also acknowledges some limitations and therefore outlines further research opportunities.

First, the conceptual teaching framework using LSP has been developed from both research and practicebased experience by the authors, however in this study it has yet to be empirically tested. We call on researchers to further refine the model and revisit early assumptions around each step of the process. Second, the scalability of delivery is considered as an element that requires further input. For example,
LSP is reliant on the use of materials, which in this case are primarily Lego bricks, and require the educator's attention when teaching a manageable cohort of individuals. Therefore, we suggest that further investigation is required to examine and understand the balance between group size and delivery of content focused on responsible education management. Third, this research outlines one innovative teaching methodology that can help educators create effective learning environments for management students. We call for research into, and the conceptualisation of, other innovative teaching methodologies and tools that can assist educators deliver engaging content. In summary, in this paper we have developed a framework for educators who are interested in enhancing the delivery of their educational sessions to better prepare their students for pressing future global challenges.

\section{References}

Aragon-Correa, J. A., Marcus, A. A., Rivera, J. E., \& Kenworthy, A. L. (2017). Sustainability management teaching resources and the challenge of balancing planet, people, and profits. In Academy of Management Learning and Education (Vol. 16, Issue 3). http://dx.doi.org/10.5465/amle.2017.0180

Arbaugh, J. B., Bento, R., \& Hwang, A. (2010). Does the MBA Experience Support Diversity? Demographic Effects on Program Satisfaction*. Decision Sciences Journal of Innovative Education, 8(2).

http://dx.doi.org/10.1111/j.1540-4609.2010.00267.x

Ayres, R. U., \& Ayres, L. (Eds.). (2015). A handbook of industrial ecology. Edward Elgar Publishing.

Bansal, P., \& Roth, K. (200o). Why companies go green: A model of ecological responsiveness. Academy of Management Journal, 43(4), 717-736.

http://dx.doi.org/10.5465/1556363

Bennis, W.G. and O’Toole, J., (2005). How business schools have lost their way. Harvard Business Review, 83(5), pp.96-104.

Bobby Banerjee, S. (2001). Corporate environmental strategies and actions. Management Decision, 39(1), 3644. http://dx.doi.org/10.1108/EUMoooooooo05405

Bovill, C., Cook-Sather, A., \& Felten, P. (2011). Students as co-creators of teaching approaches, course design, and curricula: Implications for academic developers.

International Journal for Academic Development, 16(2), 133-145.

http://dx.doi.org/10.1080/1360144X.2011.568690 
Bruner, J. (1961). The Act of Discovery. In Harvard Educational Review (Vol. 31, pp. 21-32).

Cagle, J. A. B., \& Baucus, M. S. (2006). Case studies of ethics scandals: Effects on ethical perceptions of finance students. Journal of Business Ethics, 64(3), 213-229. http://dx.doi.org/10.1007/s10551-005-8503-5

Cervantes, G. (2007a). A methodology for teaching industrial ecology. International Journal of Sustainability in Higher Education, 8(2), 131-141.

http://dx.doi.org/10.1108/14676370710726607

Cook-Sather, A., Bovill, C., \& Felten, P. (2014). Engaging students as partners in learning and teaching: A guide for faculty. John Wiley \& Sons

Dacre, N., Constantinides, P., \& Nandhakumar, J. (2015). How to Motivate and Engage Generation Clash of Clans at Work? Emergent Properties of Business Gamification Elements in the Digital Economy. International Gamification for Business Conference, Birmingham, UK. https://dx.doi.org/10.2139/ssrn.3809398

Dacre, N., Gkogkidis, V., \& Jenkins, P. (2018). CoCreation of Innovative Gamification Based Learning: A Case of Synchronous Partnership. Society for Research into Higher Education, Newport, Wales UK. https://dx.doi.org/10.2139/ssrn.3486496

Dacre, N., Senyo, PK., \& Reynolds, D. (2019). Is an Engineering Project Management Degree Worth it? Developing Agile Digital Skills for Future Practice. Engineering Education Research Network, Coventry, UK. https://dx.doi.org/10.2139/ssrn.3812764

Duckworth, E. (2006). The having of wonderful ideas and other essays on teaching and learning. Teachers College Press.

Dyllick, T. (2015). Responsible management education for a sustainable world The challenges for business schools. Journal of Management Development, 34(1), 16-33. http://dx.doi.org/10.1108/JMD-02-2013-0022

Eckhaus, E., Klein, G., \& Kantor, J. (2017). Experiential Learning in Management Education. Business, Management and Education, 15(1), 42-56. http://dx.doi.org/10.3846/bme.2017.345

Feldman, H. D., \& Thompson, R. C. (1990). Teaching Business Ethics: A Challenge for Business Educators in the 1990s. Journal of Marketing Education, 12(2), 10-22. http://dx.doi.org/10.1177/027347539001200203
Feinstein, A., Mann, S., \& Corsun, D. L. (2002). Charting the experiential territory:Clarifying definitions and uses of computer simulation, games, and role play. Journal of Management Development, 21(10), 732-744.

http://dx.doi.org/10.1108/02621710210448011

Forray, J. M., \& Leigh, J. S. A. (2012). A primer on the principles of responsible management education: Intellectual roots and waves of change. In Journal of Management Education (Vol. 36, Issue 3, pp. 295-309). http://dx.doi.org/10.1177/1052562911433031

Gkogkidis, V., \& Dacre, N. (2020). Co-Creating Educational Project Management Board Games to Enhance Student Engagement. European Conference on Game Based Learning, Brighton, UK. https://dx.doi.org/10.2139/ssrn.3812772

Gladwin, T. N., Kennelly, J. J., \& Krause, T.-S. (1995). Shifting Paradigms for Sustainable Development: Implications for Management Theory and Research. Academy of Management Review, 20(4), 874-907. http://dx.doi.org/10.5465/AMR.1995.9512280024

Godemann, J., Haertle, J., Herzig, C., \& Moon, J. (2014). United Nations supported Principles for Responsible Management Education: Purpose, progress and prospects. Journal of Cleaner Production, 62, 16-23. http://dx.doi.org/10.1016/j.jclepro.2013.07.033

Gold, J., \& Holman, D. (2001). Let me tell you a story: An evaluation of the use of storytelling and argument analysis in management education. Career Development International, 6(7), 384-395. http://dx.doi.org/10.1108/EUMooooooooo6054

Grienitz, V., \& Schmidt, A.-M. (2012). Scenario workshops for strategic management with Lego Serious Play. Problems of Management in the 21st ..., 3, 26-35.

Hamschmidt, J. (Ed.). (2007). Case Studies in Sustainability Management and Strategy. London: Routledge

Harrison, R. T., Leitch, C. M., \& Chia, R. (2007). Developing paradigmatic awareness in university business schools: The challenge for executive education. Academy of Management Learning and Education, 6(3), 332-343. http://dx.doi.org/10.5465/AMLE.2007.26361624

Hickey, D. T., \& Zuiker, S. J. (2005). Engaged participation: A sociocultural model of motivation with implications for educational assessment. In Educational Assessment (Vol. 10, Issue 3, pp. 277-305). http://dx.doi.org/10.1207/s15326977ea1003_7 
Hoidn, S. (2017). Student-Centered Learning Environments in Higher Education Classrooms. In Student-Centered Learning Environments in Higher Education Classrooms. Palgrave Macmillan US. http://dx.doi.org/10.1057/978-1-349-94941-o

Jabbar, A., \& Hardaker, G. (2013). The role of culturally responsive teaching for supporting ethnic diversity in British University Business Schools. Teaching in Higher Education, 18(3), 272-284.

http://dx.doi.org/10.108o/13562517.2012.725221

James, A. (2013). Lego Serious Play: a three-dimensional approach to learning development. Journal of Learning Development in Higher Education, 6, 1-18. http://dx.doi.org/10.47408/jldhe.voi6.208

King, A. (1993). From Sage on the Stage to Guide on the Side. College Teaching, 41(1), 30-35.

http://dx.doi.org/10.1080/87567555.1993.9926781

Kristiansen, P., \& Rasmussen, R. (2014). Building a better business using the Lego serious play method. John Wiley \& Sons.

Kurkovsky, S. (2015). Teaching software engineering with LEGO serious play. Annual Conference on Innovation and Technology in Computer Science Education, ITiCSE, 2015-June, 213-218.

http://dx.doi.org/10.1145/2729094.2742604

Mccusker, S. (2014). Lego® Serious Play TM : Thinking about Teaching and Learning. International Journal of Knowledge, Innovation and Entrepreneurship, Volume 2 No. 1, 2014, pp. 27-37

Mello, J. A. (2006). Enhancing the international business curriculum through partnership with the united states department of commerce: The "E" award internship program. Journal of Management Education, 3o(5), 690-699. http://dx.doi.org/10.1177/1052562906289049

Minshall, T. H. W., \& Wicksteed, W. (2005). University spin-out companies: Starting to fill the evidence gap. In $A$ report for The Gatsby Charitable Foundation

Muff, K. (2013). Developing globally responsible leaders in business schools: A vision and transformational practice for the journey ahead. In Journal of Management Development (Vol. 32, Issue 5, pp. 487-507). Emerald Group Publishing

Ojiako, U., Ashleigh, M., Chipulu, M., \& Maguire, S. (2011). Learning and teaching challenges in project management. International Journal of Project Management, 29(3), 268-278.

http://dx.doi.org/10.1016/j.ijproman.2010.03.008
Parkes, C., Buono, A. F., \& Howaidy, G. (2017). The Principles for responsible management education (PRME): The first decade - What has been achieved? The next decade - Responsible management Education's challenge for the Sustainable Development Goals (SDGs). In International Journal of Management Education (Vol. 15, Issue 2, pp. 61-65). Elsevier Ltd. http://dx.doi.org/10.1016/j.ijme.2017.05.003

Peabody, M. A., \& Noyes, S. (2017). Reflective boot camp: adapting LEGO $®$ SERIOUS PLAY® in higher education. Reflective Practice, 18(2), 232-243. http://dx.doi.org/10.1080/14623943.2016.1268117

Pfeffer, J., \& Fong, C. T. (2002). The End of Business Schools? Less Success Than Meets the Eye. Academy of Management Learning \& Education, 1(1), 78-95. http://dx.doi.org/10.5465/AMLE.2002.7373679

Piaget, J. (1972). Intellectual evolution from adolescence to adulthood. Human Development, 15(1), 1-12. http://dx.doi.org/10.1159/000112531

PRME. (2008). A global initiative, a global agenda: The principles for responsible management education. United Nations Global Compact Office.

PRME. (2014). Principles for responsible management education-United Nations global compact strategy to grow sustainable business leaders.

Rasche, A., \& Gilbert, D. U. (2015). Decoupling Responsible Management Education: Why Business Schools May Not Walk Their Talk. Journal of Management Inquiry, 24(3), 239-252. http://dx.doi.org/10.1177/1056492614567315

Rasche, A., Gilbert, D. U., \& Schedel, I. (2013). Crossdisciplinary ethics education in MBA programs: Rhetoric or reality? In Academy of Management Learning and Education (Vol. 12, Issue 1, pp. 71-85). http://dx.doi.org/10.5465/amle.2011.0016A

Rick, J., \& Lamberty, K. K. (2005). Medium-based design: Extending a medium to create an exploratory learning environment. Interactive Learning Environments, 13(3), 179-212.

http://dx.doi.org/10.1080/10494820500401883

Robson, K., Plangger, K., Kietzmann, J. H., McCarthy, I., \& Pitt, L. (2015). Is it all a game? Understanding the principles of gamification. Business Horizons, 58(4), 411420. https://doi.org/10.1016/j.bushor.2015.03.006

Robson, K., Plangger, K., Kietzmann, J. H., McCarthy, I., \& Pitt, L. (2016). Game on: Engaging customers and employees through gamification. Business Horizons, 59(1), 29-36.

https://doi.org/10.1016/j.bushor.2015.08.002 
Roos, J., Victor, B., \& Statler, M. (2004). Playing seriously with strategy. Long Range Planning, 37(6), 549-568. http://dx.doi.org/10.1016/j.lrp.2004.09.005

Salomon, G. (1997). Distributed cognitions: Psychological and educational considerations. Cambridge University Press.

Shrivastava, P. (1995). Ecocentric Management for a Risk Society. Academy of Management Review, 2O(1), 118137.

Shannon, J. R., \& Berl, R. L. (1997). Are We Teaching Ethics in Marketing?: A Survey of Students' Attitudes and Perceptions. Journal of Business Ethics, 16(10), 10591075. http://dx.doi.org/10.1023/A:1017922005651

Shrivastava, P. (1995). Ecocentric management for a risk society. Academy of management review, 2o(1), 118-137. Academy of Management Briarcliff Manor, NY 10510. http://dx.doi.org/10.2307/258889

Snelson-Powell, A., Grosvold, J., \& Millington, A. (2016). Business school legitimacy and the challenge of sustainability: A fuzzy set analysis of institutional decoupling. In Academy of Management Learning and Education (Vol. 15, Issue 4, pp. 703-723). George Washington University. http://dx.doi.org/10.5465/amle.2015.0307

Stefanova, M. D., \& Stefanova, M. (2013). Principles for responsible management education - United Nations Global Compact strategy to grow sustainable business leaders, Conference: 15th International Conference Social Sustainability through competitiveness with qualitative growth
Stubbs, W., \& Cocklin, C. (2008). Teaching sustainability to business students: Shifting mindsets. International Journal of Sustainability in Higher Education, 9(3), 206-221. http://dx.doi.org/10.1108/14676370810885844

Taylor, S., Thorpe, R. and Down, S., (2002). Negotiating managerial legitimacy in smaller organizations: Management education, technical skill, and situated competence. Journal of Management Education, 26(5), pp.550-573. http://dx.doi.org/10.1177/105256202236726

Thorpe, R., \& Rawlinson, R. (2013). The role of UK business schools in driving innovation and growth in the domestic economy. The Association of Business Schools.

Tompson, H. B., \& Tompson, G. H. (1996). International Perspective: Confronting Diversity Issues in the Classroom with Strategies to Improve Satisfaction and Retention of International Students. Journal of Education for Business, 72(1), 53-57.

http://dx.doi.org/10.1080/o8832323.1996.10116826

Vives Gabriel, J. (2017). Case Studies in Sustainability Management. In Case Studies in Sustainability Management. Routledge.

Vygotsky, L. S. (1980). Mind in society: The development of higher psychological processes. Harvard university press. http://dx.doi.org/10.2307/j.ctvjfgvz4

Wyss-Flamm, E. D., \& Zandee, D. P. (2001). Navigating Between Finite and Infinite Games in the Managerial Classroom. Journal of Management Education, 25(3), 292-307.

https://dx.doi.org/10.1177/105256290102500303 


\section{Appendices}

\begin{tabular}{|c|c|c|c|c|}
\hline \multicolumn{5}{|c|}{ Appendix 1: Lesson plan } \\
\hline $\begin{array}{l}\text { Bridge-In } \\
\text { (Motivation) }\end{array}$ & \multicolumn{4}{|c|}{$\begin{array}{l}\text { Achieve a deeper understanding of organisational sustainability issues and of the potential } \\
\text { approaches addressing these issues }\end{array}$} \\
\hline Assessment & \multicolumn{4}{|c|}{ Informal Assessment of the Analysis of the Case Study of each student/student team } \\
\hline $\begin{array}{l}\text { Learning } \\
\text { Objectives }\end{array}$ & \multicolumn{4}{|c|}{$\begin{array}{l}\text { Better understanding of how organisations approach sustainability issues, what the issues are } \\
\text { and how the decisions made by organisational leaders affect the outcome of such } \\
\text { undertakings. }\end{array}$} \\
\hline & Instructor activities & Learner activities & Resources & Time (minutes) \\
\hline $\begin{array}{l}\text { 1. Introduction to } \\
\text { the session }\end{array}$ & $\begin{array}{l}\text { State aim of session and } \\
\text { distribute register }\end{array}$ & Sign register & $\begin{array}{l}\text { PowerPoint } \\
\text { slides, } \\
\text { register }\end{array}$ & 5 \\
\hline $\begin{array}{l}\text { 2. Lego warm up } \\
\text { exercises }\end{array}$ & $\begin{array}{l}\text { Explain aim of Lego and } \\
\text { facilitate students building } \\
\text { simple Lego models (two } \\
\text { exercises) }\end{array}$ & $\begin{array}{l}\text { Build Lego models, } \\
\text { discuss Lego models } \\
\text { within their teams }\end{array}$ & $\begin{array}{l}\text { PowerPoint } \\
\text { slides, Lego } \\
\text { bricks }\end{array}$ & $\begin{array}{l}20 \text { (10 if students are } \\
\text { familiar with LSP, with } \\
\text { one instead of two } \\
\text { warm up exercises) }\end{array}$ \\
\hline $\begin{array}{l}\text { 3. Organisational } \\
\text { sustainability } \\
\text { case study }\end{array}$ & $\begin{array}{l}\text { Brief presentation of the } \\
\text { general background of the } \\
\text { case study }\end{array}$ & $\begin{array}{l}\text { Take notes of the } \\
\text { major sustainability } \\
\text { challenges presented } \\
\text { to the organisation }\end{array}$ & $\begin{array}{l}\text { PowerPoint } \\
\text { Slides }\end{array}$ & 10 \\
\hline 4. LSP question & $\begin{array}{l}\text { Introduce the first } \\
\text { question: What are the } \\
\text { main sustainability } \\
\text { problems and risks that the } \\
\text { organisation is facing? } \\
\text { Build Lego model }\end{array}$ & $\begin{array}{l}\text { Build Lego models } \\
\text { responding to the } \\
\text { question }\end{array}$ & $\begin{array}{l}\text { Lego bricks, } \\
\text { slides }\end{array}$ & 5 \\
\hline 5. LSP sharing & $\begin{array}{l}\text { Facilitate sharing of Lego } \\
\text { models, share their own } \\
\text { insights }\end{array}$ & $\begin{array}{l}\text { Share insights built } \\
\text { into Lego models }\end{array}$ & Lego bricks & $\begin{array}{l}10 \text { (timings during this } \\
\text { stage of the process } \\
\text { depend on student } \\
\text { numbers, we would } \\
\text { advise for each student } \\
\text { to be given a minute.) }\end{array}$ \\
\hline 6. LSP reflection & $\begin{array}{l}\text { Summarise themes } \\
\text { discussed during the } \\
\text { sharing stage, connect them } \\
\text { to theory }\end{array}$ & Take notes of themes & & 5 \\
\hline 7. LSP question & $\begin{array}{l}\text { Introduce the second } \\
\text { question: what are the } \\
\text { potential solutions to these } \\
\text { problems and risks, and } \\
\text { what should the business } \\
\text { do to solve these issues? }\end{array}$ & $\begin{array}{l}\text { Build Lego models } \\
\text { responding to the } \\
\text { question }\end{array}$ & $\begin{array}{l}\text { Lego bricks, } \\
\text { slides }\end{array}$ & 5 \\
\hline 8. LSP sharing & $\begin{array}{l}\text { Facilitate sharing of Lego } \\
\text { models, share their own } \\
\text { insights }\end{array}$ & $\begin{array}{l}\text { Share insights built } \\
\text { into Lego models }\end{array}$ & Lego bricks, & $\begin{array}{l}10 \text { (timings during this } \\
\text { stage of the process } \\
\text { depend on student } \\
\text { numbers, we would } \\
\text { advise for each student } \\
\text { to be given a minute to } \\
\text { present their model.) }\end{array}$ \\
\hline 9. LSP reflection & $\begin{array}{l}\text { Summarise themes } \\
\text { discussed during the } \\
\text { sharing stage, connect them } \\
\text { to theory }\end{array}$ & Take notes of themes & & 5 \\
\hline
\end{tabular}

